\title{
Acute Chagas disease outbreak associated with oral transmission
}

\author{
Surto de doença de Chagas aguda associada \\ à transmissão oral
}

\author{
Juarez Pereira Dias ${ }^{1,2}$, Claudilson Bastos ${ }^{3}$, Eline Araújo ${ }^{3}$, Ana Verônica Mascarenhas ${ }^{3}$, \\ Eduardo Martins Netto ${ }^{1}$, Fernanda Grassi ${ }^{4}$, Miralba Silva ${ }^{3}$, Erica Tatto ${ }^{5}$, Jorge Mendonça ${ }^{2}$, \\ Renato Freitas Araújo ${ }^{2}$, Maria Aparecida Shikanai-Yasuda ${ }^{6}$ and Roque Aras ${ }^{1}$
}

\begin{abstract}
Seven individuals living in a town in the Southwest of Bahia developed sudden signs of cardiac and systemic impairment, with lethality of $28.6 \%$. Serological tests were positive at least in one test in the five patients examined. Forty percent of the Triatoma sordida mynphs found inside or around Trypanosoma cruzi were found by blood culturig in there out five cases the homes of these cases were positive for Trypanosoma cruzi. Transmission probably occurred through consumption of water contaminated with triatomine feces. These findings emphasize the necessity to evaluation the importance of vectors like Triatoma sordida in maintaining the endemicity of this disease.
\end{abstract}

Key-words: Acute Chagas disease. Trypanosoma cruzi. Triatoma sordida. Epidemiology. Outbreak.

\section{RESUMO}

Sete indivíduos que viviam em uma cidade do sudoeste da Bahia desenvolveram sinais súbitos de envolvimento cardíaco e sistêmico com letalidade de 28,6\% Trypanosoma cruzi foi isolado por hemocultura em três de cinco casos examinados. Testes sorológicos foram positivos em mais de um teste nos cinco pacientes, que os realizaram. Qinquenta por cento dos Triatoma sordida encontrados na residência ou no peridomicilio dos casos estavam positivos para Trypanosoma cruzi. A transmissão provavelmente foi devido à ingestão de água contaminada por fezes de triatomíneos. Estes achados enfatizam a necessidade de se avaliar a importância de vetores como Triatoma sordida na manutenção da endemicidade da doença.

Palavras-chaves: Doenças de Chagas aguda. Trypanosoma cruzi. Triatoma sordida. Epidemiologia. Surto.

Chagas disease is an anthroponosis caused by Trypanosoma cruzi. This disease is still an important public health problem, particularly in poor places where the houses are made of mud. This type of construction favors infestation by the vector triatomines ${ }^{11}$. The disease is prevalent from the Southern United States to Southern Argentina. It has been estimated by the World Health Organization that 16 to 18 million people now present chronic infection ${ }^{18}$. In Brazil, the national seroprevalence survey that was concluded in 1980 showed a prevalence of $4.2 \%$ in rural areas and $3.1 \%$ among the whole population ${ }^{7}$. The original endemic zone in Brazil outside of the Amazon region goes from the State of Maranhão to the State of Rio Grande do Sul, with the exception of the State of Santa Catarina. In 2005, 2,392 individuals were hospitalized in Brazil with chronic Chagas disease; the public health system expended eight million reais on these patients ${ }^{14}$.
Advances in controlling domestic triatomine populations in South America, and particularly in Brazil, have contributed towards reductions in vector transmission, especially of Triatoma infestans. These advances have included vector control programs using insecticides and, to a lesser but far from negligible extent, better sanitary conditions ${ }^{22}$. There have been additional reductions in transmission through blood and congenitally by means of a well-designed cleanblood transfusion program and diagnosis and treatment programs for women of fertile ages. Nevertheless, despite these advances, a few occurrences of transmission are still being reported, especially in the Amazon region. These have been caused by congenital transmission, organ transplantation, laboratory accidents and, most recently, oral transmission suspected to be due to assai juice consumption?

The object of this paper was to describe an outbreak of acute Chagas disease among individuals in a single household in a small town in Bahia.

1. Hospital Universitário Prof. Edgard Santos, Universidade Federal da Bahia, Salvador, BA. 2. Diretoria de Vigilância Epidemiológica, Secretaria de Saúde do Estado da Bahia, Salvador, BA. 3. Hospital Couto Maia, Salvador, BA. 4. Fundação Oswaldo Cruz, Rio de Janeiro, RJ. 5. Secretaria de Vigilância da Saúde, Ministério da Saúde, Brasília, DF. 6. Faculdade de Medicina, Universidade de São Paulo, São Paulo, SP.

Address to Dr. Juarez Pereira Dias. Av. Sete de Setembro 2493/404, Vitória, 40080-003 Salvador, BA.

Tel: 55 71-3336-6419; Fax: 55 71-3270-5820

e-mail: juarez@saude.ba.gov.br

Recebido para publicação em: 05/11/2007

Aceito em: 02/05/2008 
Case summaries. Two sequential deaths of previously healthy individuals from the same family, associated with acute febrile disease with cardiorespiratory manifestations, led to clinical suspicion of acute Chagas disease (no necropsy was performed). The municipal health surveillance agents' attention was drawn to this and they requested assistance from the State Epidemiological Surveillance Department of Bahia to investigate the cases. Consequently, five individuals, case 1 to 5, were admitted to the state hospital for infectious diseases (Hospital Couto Maia) because they presented signs and symptoms that resembled those of the individuals who died. The case descriptions were as follows:

Case 1. LPB, an 18-year-old male, started presenting bilateral periocular edema, abdominal pain irradiating to the chest, dyspnea and palpitations upon moderate effort, on April 19.

Case 2. MAMF, an 11-year-old male, along with periocular edema, abdominal pain irradiating to the chest and fever, on April 20; however, he had become asymptomatic by the $31^{\text {st }}$ day after admission.

Case 3. JMBM, a 14-year-old female, presented fever, headache, malaise and periocular edema on April 21. Three day later, she presented dyspnea, myalgia, somnolence, prostration, chest pain, cough and epigastric pain.

Case 4. APB, a 42-year-old female who was the mother in the household, started presenting dyspnea, facial edema and lowerlimb edema on April 21. On May 6, she was hospitalized (together with cases 1, 2 and 3) with chest pain, anasarca, intense dyspnea, tachycardia and dizziness. On an electrocardiogram, she presented atrial fibrillation. She was sent to the intensive care unit.

Case 5. MJPN, a 13-year-old male who lived in the same neighborhood as the other cases and was a frequent guest in their home, presented coughing, vomiting, abdominal pain and fever on April 3. At the local health clinic, he received nbutylscopolamin bromide (10mg) + dipyrone (500mg) for pain; and dexamethasone (10mg) twice day and five drops of fenoterol hydrobromide $(0.1 \mathrm{mg})$ nebulization for asthma. He was then asymptomatic for 20 days. On April 23, he presented fever, abdominal and chest pain, dyspnea and facial edema. He went back to the health clinic and was administered antibiotics.

Case 6. RBAM, a 16-year-old male, presented fever, cough, headache, myalgia, malaise and abdominal pain on April 24. On April 26, he presented hypotension, dyspnea, tachycardia, cardiomegaly and pericardial effusion on chest x-ray. On electrocardiogram, he presented complete right-branch block and diffuse repolarization abnormalities. On May 5, the patient died due to heart failure.

Case 7. LBAM, a 9-year-old male, developed headache, fever, myalgia and vomiting on April 5. At the local health clinic, it was suspected that this was a case of dengue fever. He was medicated with paracetamol 1,500mg/d and sent home. On April 24, the clinical symptoms returned, together with abdominal pain, dyspnea, anasarca, hepatomegaly and left pleural effusion. On April 29, he developed sudden respiratory failure and died on the same day.

Patients 1, 2, 3 and 4 were hospitalized on April 6, 2006, and patient 5 on May 10, 2006. All the patients were discharged on May 19 and had become asymptomatic by the $43^{\text {rd }}$ day after admission, through specific treatment with benznidazole (5 mg/kg/day/60 days).

Epidemiological investigation. The patients were from Macaúbas, a town with a population of 41,800 inhabitants, located $680 \mathrm{~km}$ from Salvador, the capital of Bahia. The city is in the Chapada Diamantina region, at an altitude of 700 meters above sea level. The weather is mainly dry and the mean temperature is $22^{\circ} \mathrm{C}(8)$.

The family's home was located in the urban area and was made of mud and brick. It was poorly built, with many cracks in the walls, floors and ceilings. There were rodent burrows in the rooms. Chicken droppings were seen in the house, along with the remains of cockroaches and scorpions. The house was surrounded by bushes, and there was open discharge of sewage and waste. There was an open water container outside the house. Near the house, there was a small forest.

Seven people were living in the house at the time of the outbreak. They were members of a single family (father, mother and five children). All members of the household normally had their meals inside the house, prepared by the mother (Case 4). They reported that they had been consuming soft drinks made of manufactured powder, water and sugar. The water bottles were kept under the kitchen sink, mostly without a cap.

Two parties were held in the house shortly before the outbreak: one on March 12, 2006, and the other on March 26, 2006 (respectively, 24 and 10 days before the day the symptoms of the first case started). On these occasions, around 40 relatives and friends were served with cookies and crackers, all made in the house, and manufactured soft drinks (Figure 1).

Entomological results. Several specimens of triatomines were found around and inside the house. They were nymphs of Triatoma sordida (Stal, 1859), in stages 2 to 5. Fifty percent of the triatomines were positive for Trypanosoma cruzi in direct parasitological examination of their feces. Triatomine feces were also examined to determine the food source, by means of precipitin tests as described by Siqueira (9). These tests were positive for: birds $\left(n^{0}=10\right)$, opossums $\left(n^{0}=6\right)$, rodents + birds $\left(\mathrm{n}^{\mathrm{o}}=1\right)$, opossums + birds $\left(\mathrm{n}^{\mathrm{0}}=1\right)$, opossums + rodents $\left(n^{0}=2\right)$ and humans $\left(n^{0}=1\right)$. Triatomine feces were found under the kitchen sink, near the water and refreshments containers. Forty percent of the Triatoma sordida found in a survey performed within a radius of five hundred meters around the house were infected with Trypanosoma cruzi. Three opossums were captured, and one was found to be positive for Trypanosoma cruzi, using the Enzyme-Linked ImmunoSorbent Assay (ELISA). Samples of manioc flour and sugar that were collected in the house for physical and chemical analysis showed the presence of dust mites and insects (whole and fragmented).

Laboratory tests. Parasites were found in cases 2, 4 and 5 by blood culturing. No parasite examinations were performed on cases 1,6 and 7. The five hospitalized patients were positive in at least one of the following serological tests: passive hemagglutination (HA); indirect immunofluorescence (RIFI); ELISA IgG and IgM; and immunoblot (IgG) (Table 1). 


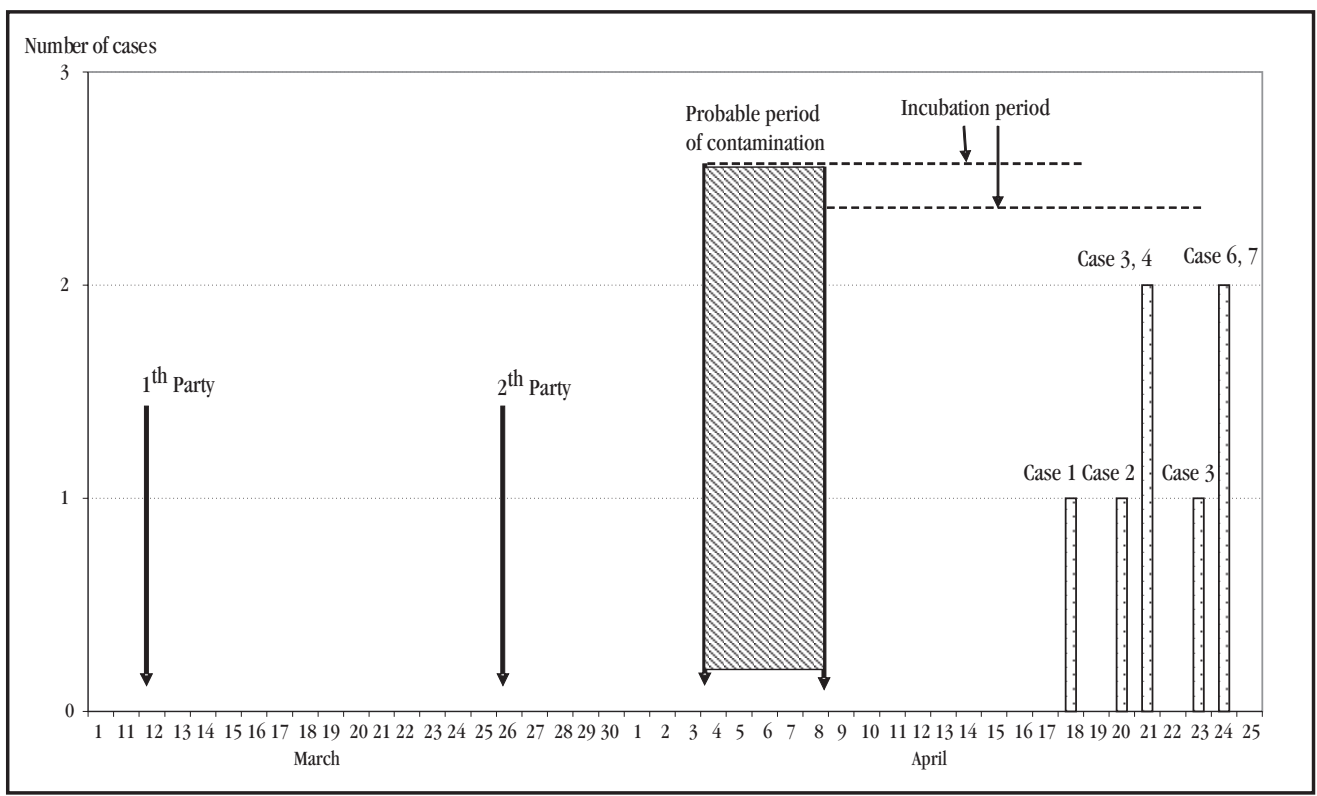

Figure 1 - Timeline: dates when the parties were beld, and dates when the first symptoms of acute Chagas disease appeared. Macaúbas, Babia, Brazil, 2006.

Table 1 -Diagnostic serological test results from five patients with acute Chagas disease in Macaúbas, Bahia, Brazil, 2006.

\begin{tabular}{|c|c|c|c|c|c|}
\hline \multirow[t]{2}{*}{$\begin{array}{l}\text { Nome } \\
\text { (Case) }\end{array}$} & \multirow[t]{2}{*}{$\begin{array}{l}\text { HA } \\
\text { (passive } \\
\text { agglutination) }\end{array}$} & \multicolumn{2}{|c|}{$\begin{array}{c}\text { RIFI } \\
\text { (indirect } \\
\text { immunofluorescence) }\end{array}$} & \multirow[t]{2}{*}{$\begin{array}{c}\text { ELISA } \\
\text { IgG }\end{array}$} & \multirow{2}{*}{$\begin{array}{c}\text { Immunoblot } \\
\text { (IgG antibodies } \\
\text { against Trypanosom } \\
\text { a cruzi antigen) }{ }^{5}\end{array}$} \\
\hline & & IgM & $\operatorname{IgG}$ & & \\
\hline $\begin{array}{l}\text { LPB } \\
\text { (Case 1) }\end{array}$ & $\begin{array}{l}\text { positive }^{1} \\
\text { positive }^{2} \\
\text { negative }^{6}\end{array}$ & $\begin{array}{l}1 / 120^{1} \\
1 / 40^{2} \\
1 / 20^{6}\end{array}$ & $\begin{array}{c}\text { positive }^{1} \\
1 / 160^{2} \\
1 / 320^{6} \\
\end{array}$ & $\begin{array}{l}\text { positive } \\
\text { positive }^{2} \\
\text { positive }^{6} \\
\end{array}$ & positive \\
\hline $\begin{array}{l}\text { MAMF } \\
\text { (Case 2) }\end{array}$ & $\begin{array}{l}\text { negative }^{1} \\
\text { negative }^{2} \\
\text { negative }^{6}\end{array}$ & $\begin{array}{c}1 / 30^{1} \\
1 / 80^{2} \\
\text { negative }^{6}\end{array}$ & $\begin{array}{c}\text { positive }^{1} \\
1 / 160^{2} \\
\text { negative }^{6}\end{array}$ & $\begin{array}{l}\text { positive } \\
\text { positive }^{2} \\
\text { positive }^{6}\end{array}$ & positive \\
\hline $\begin{array}{l}\text { JMBM } \\
\text { (Case 3) }\end{array}$ & $\begin{array}{l}\text { negative }^{1} \\
\text { positive }^{2} \\
\text { negative }^{6}\end{array}$ & $\begin{array}{l}1 / 30^{1} \\
1 / 320^{2} \\
1 / 80^{6}\end{array}$ & $\begin{array}{c}\text { positive }^{1} \\
1 / 80^{2} \\
1 / 80^{6}\end{array}$ & $\begin{array}{l}\text { positive } \\
\text { positive }^{2} \\
\text { positive }^{6}\end{array}$ & positive \\
\hline $\begin{array}{l}\text { APB } \\
\text { (Case 4) }\end{array}$ & $\begin{array}{l}\text { negative }^{1} \\
\text { negative }^{2} \\
\text { negative }^{6} \\
\end{array}$ & $\begin{array}{c}1 / 30^{1} \\
1 / 160^{2} \\
\text { negative }^{6} \\
\end{array}$ & $\begin{array}{c}\text { positive }^{1} \\
1 / 80^{2} \\
1 / 80^{6} \\
\end{array}$ & $\begin{array}{l}\text { positive } \\
\text { positive }^{2} \\
\text { positive }^{6} \\
\end{array}$ & positive \\
\hline $\begin{array}{l}\text { MJPN } \\
\text { (Case 5) }\end{array}$ & $\begin{array}{l}\text { positive }^{3} \\
\text { negative }^{4} \\
\text { negative }^{6}\end{array}$ & $\begin{array}{l}1 / 30^{3} \\
1 / 40^{4} \\
1 / 10^{6}\end{array}$ & $\begin{array}{c}\text { positive }^{3} \\
1 / 80^{4} \\
\text { negative }^{6}\end{array}$ & $\begin{array}{l}\text { positive } \\
\text { positive }^{4} \\
\text { positive }^{6}\end{array}$ & positive \\
\hline
\end{tabular}

1. Samples collected on May 5, 2006, and processed by LACEN/BA and 2-FUNED/MG.

3. Samples collected on May 10, 2006, and processed by LACEN/BA and 4-FUNED/MG.

5. Samples collected on May 10, 2006, and processed by Medical/Immunological Investigation Lab, Hospital das Clínicas/FMUSP.

6. Samples collected on May 15, 2006, and processed by FUNED/MG.

Patients LBAM (case 7) and RBAM (case 6) and LBAM (case 7) did not undergo serological tests.

Among the 40 people who went to the parties, 21 agreed to be tested for Chagas disease. All the tested individuals were negative in the HA, RIFI, immunoblot (IgG) and ELISA (IgG and IgM) tests and in direct examinations (fresh, concentrated drop, slide and Strout).

It was concluded that all the cases presented acute Chagas disease, through laboratory and clinic evidence in the five cases of survival and epidemiological criteria in the two cases of death.
Clinical presentation. The most frequent symptoms in the acute phase were periocular edema (100\%), dyspnea (86.5\%), fever, myalgia, prostration, cough, systolic murmurs, hepatomegaly and chest pain $(71.4 \%)$, abdominal pain, increased heart area (57.1\%). Systolic murmur and hepatomegaly occurred in $71.4 \%$ of the cases $\left(n^{0}=5\right)$. All the patients underwent chest $x$-ray examination and four of them $(57.1 \%)$ were found to present enlarged heart area. Electrocardiogram abnormalities were observed in all of the hospitalized cases $\left(\mathrm{n}^{0}=5\right)$. Fifty percent of the patients presented right-branch block. One of the seven cases (case 4), who presented the largest hemodynamic instability, presented atrial fibrillation and flutter rhythm. Echocardiograms revealed pericardial effusion in three of the five hospitalized patients.

Laboratory presentation. Passive hemagglutination presented low sensitivity: only four out of the fifteen samples from the five patients tested positive. It was noteworthy that there were low numbers of positive findings in the RIFI IgM test, whereas the opposite was found for IgG. In two patients, (cases 2 and 5) the third sample was negative, which can probably be correlated with the test sensitivity, since the other tests were positive and remained so (Table 1). The blood culture shows that three out of the five patients were positive 60 days after and remained positive for up to 120 days. However, none of the mouse inoculated with Trypanosoma cruzi developed the disease (Table 2).

Table 2 - Results from blood culturing and mouse inoculation before treatment for Trypanosoma cruzi from five patients with acute Chagas disease in Macaúbas, Babia, Brazil, 2006.

\begin{tabular}{|c|c|c|c|c|c|}
\hline \multirow[t]{2}{*}{ Patient } & \multicolumn{3}{|c|}{ Blood culturing } & \multicolumn{2}{|c|}{ Mouse inoculation } \\
\hline & 40 days & 60 days & 120 days & $1^{\mathrm{a}}$ inoculation & $2^{\mathrm{a}}$ inoculation \\
\hline LPB (Case1) & negative & negative & negative & negative & negative \\
\hline MAMF (Case 2) & negative & positive & positive & negative & negative \\
\hline JMBM (Case 3) & negative & positive & positive & negative & negative \\
\hline APB (Case 4) & negative & positive & positive & negative & negative \\
\hline MJPN (Case5) & negative & negative & negative & negative & negative \\
\hline
\end{tabular}

Source: Experimental Chagas Disease, Autoimmunity and Cell Immunity Laboratory, "Prof. Gonçalo Moniz" Central Public Health Laboratory, Gonçalo Moniz Research Center, Oswaldo Cruz Foundation, Bahia. 


\section{DISCUSSION}

As a consequence of intensive campaigns to eliminate domestic triatomines, Brazil has successfully reduced epidemic vector transmission of Trypanosoma cruzi. In addition, there are no recent reports of transmission due to Triatoma infestans ${ }^{15}$. However, outbreaks due to contaminated food are being reported with increasing frequency ${ }^{5}$. The following reports of acute Chagas disease outbreaks caused by oral transmission can be highlighted: in Rio Grande do Sul ${ }^{17}$ in 1969, during a meal; in Paraíba ${ }^{21}$ in 1985; in Santa Catarina ${ }^{13}$ in 2005, due to consumption of sugar cane juice; in Riacho de Santana ${ }^{12}$ and the San Francisco River valley ${ }^{3}$, both in Bahia in 2004; and in the Amazon region due to consumption of assai juice in 2004 and $2007^{19}$. Thus, it is recognized that clusters of acute Chagas disease cases involving a single transmission source and time can occur. In acute Chagas disease cases, although Trypanosoma cruzi is very frequently found in peripheral blood samples, it is often not seen.

In this outbreak, the contamination most probably occurred through soft drinks and/or water that had been inadequately stored. Because they were kept in open containers, they could have become contaminated by the excrement of infected triatomines. Such excrement was observed in the same place where these containers were kept. Furthermore, no inoculation point in either the skin or the periocular region, caused by direct vector transmission, could be detected in any of the individuals involved in this outbreak. The finding of high (40\%) prevalence of Trypanosoma cruzi infection in colonies of Triatoma sordida that were found near the house, i.e. much higher than the $11.5 \%$ found in other studies ${ }^{3}$.

Other reports on similar transmission sources have demonstrated high lethality rates ${ }^{1921}$, as found in the present study (28.6\%). This draws attention to three problems. 1) The need for better awareness: in other words, patients living in regions where triatomines are endemic who present prolonged fever (> seven days) or acute cardiovascular signs need to be dealt with as suspected case of acute Chagas disease, require better and faster evaluation and must undergo parasitological blood testing, to reduce the lethality rate ${ }^{6} .2$ ) The need for better and quicker diagnosis: the World Health Organization has stressed the importance of developing a test that is more specific and sensitive than those that are available on the market for diagnosing infection by Trypanosoma cruzi $i^{1623}$. The urgency of this need was echoed by other authors ${ }^{24}$ who suggested that other techniques such as ELISA using recombinant antigens and immunoblot with antigens secreted or excreted by trypomastigotes (TESAblot) could be used. These could contribute significantly towards diagnostic clarification for purposes such as blood donation. 3) The need for better control measures: there is ever-greater contact inside and around homes with species other than Triatoma infestans that were not very important for vector transmission in the past because they used to be found only in natural ecotopes ${ }^{10}$, for example
Triatoma sordida. Their epidemiological importance regarding vector transmission of Chagas disease is still $10 w^{8}$, but they may become a bigger problem if they become domesticated, thereby occupying the empty place left by the disappearance of Triatoma infestans.

\section{ACKNOWLEDGEMENTS}

Soraia Pereira Bezerra, Municipal Health Department of Macaúbas; Telma Maria de Jesus, Epidemiological Surveillance Service of Macaúbas; Elizete Amaral and Debra Lopes, DIVISA/SESAB, Suelene Navarro Araújo and Moacir Paranhos Silva, "Prof. Gonçalo Moniz" Central Laboratory of the State of Bahia; Sônia Andrade and Mitermayer Galvão Reis, Gonçalo Moniz Research Center, Oswaldo Cruz Foundation, Bahia; Marcos T. Obara, Health Surveillance Department, Ministry of Health.

\section{REFERENCES}

1. Akhavan B. Programa das Nações Unidas para o Desenvolvimento/Fundação Nacional de Saúde Análise do custo-benefício do Programa de Controle da Doença de Chagas no Brasil, 1996.

2. Aras R, Gomes I, Veiga M, Melo A. Transmissão vetorial da Doença de Chagas em Mulungu do Morro, Nordeste do Brasil. Revista da Sociedade Brasileira de Medicina Tropical 36: 359-363, 2003.

3. Barbosa PRB. The oral transmission of Chagas' disease: An acute form of infection responsible for regional outbreaks. International Journal of Cardiology 112: 132-133, 2006.

4. Barrett TV, Hoff RH, Mott KE, Guedes F, Sherlock IA. An outbreak of acute Chagas's disease in the São Francisco Valley region of Bahia, Brazil: triatomine vectors and animal reservoirs of Trypanosoma cruzi. Transactions of the Royal Society of Tropical and Medicine Hygiene 73: 703-709, 1979.

5. Bastos CC. Uso dos Antígenos Recombinantes (AR) de Trypanosoma cruzi no Teste de diagnóstico para Doença de Chagas, em Salvador, BA. Master's dissertation, Universidade Federal da Bahia, Salvador, Bahia, 1999.

6. Camargo EP, Silva GR, Castilho EA, Silveira AC. Inquérito sorológico da prevalência da infecção chagásica no Brasil 1975-1980. Revista do Instituto de Medicina Tropical de São Paulo 26: 192-204, 1984

7. Camargo, ME. Diagnóstico sorológico da doença de Chagas. Ars Curandi Cardiologia 9: 29-38, 1987.

8. Dias JCP. Chagas disease, environment, participation, and the state (Cited 2006 Sep 27). Available from http://www.scielo.br, 2001. Cadernos de Saúde Pública 17 (supl): 165-169, 2001

9. Dias JCP, Coura JR. Epidemiologia. In: Dias JCP, Coura JR (orgs) Clínica e Terapêutica da doença de Chagas. Uma abordagem prática para o clínico geral. Editora Fundação Oswaldo Cruz, Rio de Janeiro, p. 33-64, 1997.

10. Dias JCP, Machado EMM, Fernandes AL, Vinhais MC. Esboço geral e perspectiva da doença de Chagas no Nordeste do Brasil. Cadernos de Saúde Pública 16: 13-34, 2000.

11. Ferreira MS, Lopes ER, Chapadeiro E, Dias JCP, Ostermayer AL. Doença de Chagas. In. Veronesi R, Focaccia $\mathrm{R}$ (eds) Tratado de Infectologia. $2^{\text {nd }}$ edition, Editora Atheneu, São Paulo p. 1195-1233, 2002.

12. Maguire JH, Hoff R, Sleigh AC, Mott KE, Ramos NB, Sherlock IA. An outbreak of Chagas' disease in southwestern Bahia, Brazil. The American Journal of Tropical and Medicine Hygiene 35: 931-9366, 1986.

13. Ministério da Saúde. Secretaria de Vigilância em Saúde. Nota técnica de 29/03/2005. Available from http://www.saude.gov.br/svs, 2006, 2005.

14. Ministério da Saúde. Sistema de Informações Hospitalares do SUS (SIH/SUS). Available from http://www.datasus.gov.br, 2006. 
15. Ministério do Planejamento, Orçamento e Gestão. Instituto Brasileiro de Geografia e Estatística - FIBGE. Available from http://www.ibge.gov.br, 2006.

16. Moncayo A, Luquetti A0. Multicentre double blind study for evaluation of Trypanosoma cruzi defined antigens as diagnostic reagents (+). Memórias do Instituto Oswaldo Cruz 85: 489-495,1990.

17. Nery-Guimarães F, Silva NN, Calusell DT, Mello AL, Rapone T, Snell T, Rodrigues N. Um surto epidêmico de doença de Chagas de provável transmissão digestiva, ocorrido em Teutônia (Estrela, Rio Grande do Sul). Hospital 73: 1767-1804, 1968

18. Pan America Health Organization PAWHO. Health conditions in the Americas. Scientific Publication 524, Washington, DC, 1990.

19. Pinto AYC, Valente SAS, Valente VC. Emerging acute Chagas disease in Amazonian Brazil: case reports with serious cardiac involvement. Brazilian Journal of Infectious Diseases 8: 454-460, 2004.
20. Siqueira A F. Estudos sobre a reação de precipitina aplicada a identificação do sangue ingerido por triatomíneos. Revista do Instituto de Medicina Tropical de São Paulo 2: 41-53, 1960

21. Shikanai-Yasuda MA, Marcondes CB, Guedes LA, Siqueira GS, Barone AA, Dias JCP, Amato Neto V, Tolezano JE, Peres BA, Arruda Júnior ER, Lopes MH, Shiroma M, Chapadeiro E. Possible oral transmission of acute Chagas' disease in Brazil. Revista do Instituto de Medicina Tropical de São Paulo 33: 351-357,1991.

22. World Health Organization. Control of Chagas Disease. Second report of the WHO Expert Committee. Geneva. WHO Technical Reports Series 905, p. 109, 2002.

23. Yasuda MAS. A doença de Chagas em centros urbanos. Jornal do Conselho Federal de Medicina (14), 1998.

24. Yasuda MAS. Chagas: Novas características da endemia em centros urbanos Médicos Hospital das Clínicas - Faculdade de Medicina da Universidade de São Paulo 1: 26-31, 1998. 